\title{
INVENTORY OF BUTTERFLY SPECIES (LEPIDOPTERA: PAPILIONOIDEA) IN SEVERAL HABITAT TYPES IN UNIVERSITY OF BANGKA BELITUNG
}

\author{
Elfrida Natalia Manurung ${ }^{1) *}$, Budi Afriyansyah ${ }^{1)}$, Hari Sutrisno ${ }^{2)}$ \\ ${ }^{1)}$ Program studi Biologi, Fakultas Pertanian, Perikanan dan Biologi, Universitas Bangka Belitung \\ Desa Balunijuk Kec. Merawang, Kab. Bangka, Prov Kepulauan Bangka Belitung, 33172, Indonesia \\ ${ }^{2)}$ Lembaga Ilmu Pengetahuan Indonesia, Cibinong Science Center, \\ Jl. Raya Jakarta-Bogor KM. 46 Cibinong 16911, Indonesia
}

\author{
ARTICLE INFO \\ Article history: \\ Received 05 Mar 2021, \\ Revised 07 Jun 2021, \\ Accepted 22 Jul 2021 \\ Available online 30 July 2021

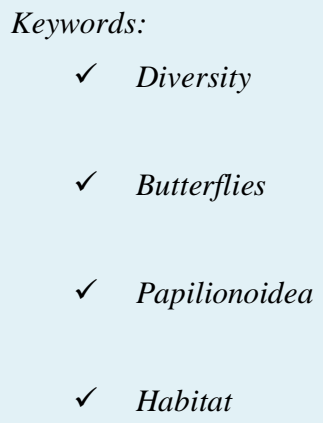

*corresponding author: elfridanm@gmail.com Phone: +6282111316254

Doi:

https://doi.org/10.31938/jsn.v $11 \mathrm{i} 2.305$

\begin{abstract}
Butterflies (Papilionoidea) are Lepidoptera which have various ecological roles in maintaining the balance of the ecosystem and can be found in various types of habitats ranging from forest to urban areas. This research was conducted from March to June 2020 in four types of habitat, namely, rubber gardens, secondary forest, agroecosystem hatchery, and swamp forest using the Pollard transect method and the sweeping net technique for five days in each habitat type. The relationships between environmental factors and the number of species and individuals were analyzed with the Pearson correlation test. The number of individual butterflies obtained was 913 butterflies of 27 species from five families (Nymphalidae, Pieridae, Lycaenidae, Hesperidae, and Riodinidae). The highest diversity was found in rubber gardens (19 species) followed by secondary forest (17 species), swamp forest (12 species) and agroecosystem hatchery (10 species). The highest species diversity index was found in swamp forests, while the lowest was in the agroecosystem hatchery habitat. The types of butterflies found in all habitats are Eurema sari, Mycalesis horsfieldi and M. mineus. The most abundant butterfly family is Nymphalidae. The Pearson correlation test analysis results showed a relationship between environmental factors and the number of species and individuals found.
\end{abstract}

\section{ABSTRAK \\ Inventarisasi jenis kupu-kupu (Lepidoptera: Papilionoidea) di beberapa tipe habitat di Universitas Bangka Belitung}

Kupu-kupu (Papilionoidea) merupakan Lepidoptera yang memiliki berbagai peran ekologis dalam menjaga keseimbangan ekosistem serta dapat ditemukan di berbagai macam tipe habitat mulai dari kawasan hutan hingga perkotaan. Penelitian ini dilakukan pada bulan Maret sampai Juni 2020 di empat tipe habitat yaitu, kebun karet, hutan sekunder, hatchery agroekosistem, dan hutan rawa dengan menggunakan metode transek Pollard dan teknik sweeping net selama lima hari di masing-masing tipe habitat. Hubungan faktor lingkungan dengan jumlah spesies dan jumlah individu dianalisis dengan uji korelasi Pearson. Jumlah individu kupu-kupu yang diperoleh sebanyak 913 ekor yang terdiri dari 27 spesies yang berasal dari lima famili (Nymphalidae, Pieridae, Lycaenidae, Hesperidae, dan Riodinidae). Keanekargaman tertinggi didapatkan di habitat kebun karet (19 spesies) selanjutnya diikuti hutan sekunder (17 spesies), hutan rawa (12 spesies) dan hatchery agroekosistem (10 spesies). Indeks keanekaragaman jenis paling tinggi ditemukan di hutan rawa, sedangkan yang paling rendah pada habitat hatchery agroekosistem. Jenis kupu-kupu yang ditemukan di seluruh habitat yaitu Eurema sari, Mycalesis horsfieldi dan M. mineus. Famili kupu-kupu yang paling melimpah Nymphalidae. Hasil analisis uji kolerasi pearson, menunjukkan adanya hubungan antara faktor lingkungan dengan jumlah spesies dan individu yang ditemukan.

Kata kunci: keanekaragaman, kupu-kupu, Papilionoidea, habitat 


\section{PENDAHULUAN}

Kupu-kupu merupakan ordo Lepidopetra yang tergolong memilki sayap bersisik (Peggie \& Amir 2006). Kupu-kupu merupakan serangga holometabolan yang kelangsungan hidupnya tergantung pada ketersedian tanaman pakan (Bahar et al. 2016). Menurut Peggie (2014), sub ordo Rhopalocera digolongkan ke dalam dua superfamili yaitu Hesperioidea (skipper) hanya memiliki satu famili yaitu Hesperiidae dan Papilionoidea (kupu-kupu yang sebenarnya). Di daerah tropis sangat sering dijumpai kupu-kupu tersebut (Helmiyetti et al. 2012).

Faktor yang berpengaruh pada keanekaragaman kupu-kupu di suatu wilayah seperti geografis, ketinggian, suhu, kelembaban, intensitas cahaya, curah hujan, musim dan predator (Efendi 2009). Keanekaragaman flora di suatu kawasan dapat mempengaruhi kekayaan jenis kupu-kupu (Dewenter \& Tscharntke, 2000).

Luas lahan yang dimiliki Universitas Bangka Belitung mencapai 152 ha dan jumlah lahan yang telah di buka untuk sarana dan prasana kampus 5,98 ha (Renstra UBB, 2017). Universitas Bangka Belitung memiliki tipe habitat yang masih bersifat alami dan tidak alami atau telah mengalami perubahan seperti menjadi areal perkuliahan, areal kebun percobaan penelitian dan areal hatchery.

Habitat kupu-kupu yang terdapat di Universitas Bangka Belitung berupa hutan sekunder dan hutan rawa yang masih alami, dan lahan terbuka seperti areal kebun percobaan penelitian, dan hatchery. Pendataan keanekaragaman kupu-kupu di Bangka Belitung masih perlu untuk dilakukan. Sehingga penelitian mengenai keanekaragaman kupu-kupu di beberapa tipe habitat dianggap penting agar dapat membatu data mengenai keanekargaman jenis kupu-kupu di Bangka Belitung. Penelitian terdahulu sudah di lakukan oleh (Wiranti et al. 2019 ) Short Communication: The diversity of butterflies (Superfamily Papilionoidea) as a success indicator of tin-mined land revegetation.

Penelitian dilakukan untuk mengetahui keanekaragaman kupu-kupu dan menganalisis ada tidaknya hubungan antara karakteristik habitat dengan keanekaragaman jenis kupu-kupu (Lepidoptera: Papilionoidea) dibeberapa tipe habitat, seperti penelitian keanekaragaman kupukupu di Kampus Pinang Masak Universitas
Jambi yaitu hasil penelitian ditemukan 143 individu dari 5 famili yaitu famili Papilionidae, Pieridae, Nymphalidae, Lycaenidae dan Hesperiidae dengan indeks keanekaragaman jenis yaitu 2,153 (Dewi et al. 2016).

\section{BAHAN DAN METODE}

\section{Bahan dan alat}

Alat-alat yang digunakan dalam penelitian ini adalah, alat tulis, anemometer, buku identifikasi kupu-kupu (Butterflies of West Malaysia and Singapore second Edition (Fleming 2009), Butterflies of The South East Asian Islands Part I Papilionidae, Part II Pieridae, Danaidae, Part III Satyridae, Part IV Nymphalidae (I), dan Part V Nymphalidae (II)(Tsukada1991) dan Practical Guide to the Butterfly of Bogor Botanic Garden (Peggie \& Amir 2006)) , gunting, GPS (global position system), jaring serangga (sweeping net), jarum insekta, jarum pentul, jarum suntik, kamera, kotak koleksi, lampu essential 5 watt, luxmeter, papan perentang, pinset insekta, dan termohigrometer.

Bahan yang digunakan adalah kapur barus, kertas minyak (amplop kupu-kupu), kotak kardus, kupu-kupu hasil koleksi di lapangan, label, dan styrofoam.

\section{Metode}

Penelitian ini dilaksanakan pada bulan Maret sampai Juni 2020 bertempat di Hutan Kampus Universitas Bangka Belitung Desa Balunijuk, Kec. Merawang Kab. Bangka.

Habitat yang menjadi titik penelitian ini adalah habitat kebun karet, hutan sekunder, hatchery dan agroekosistem, dan hutan rawa. Berdasarkan hasil pengamatan di lapangan, struktur pada setiap stasiun memiliki ciri pembeda seperti perbedaan vegetasi, tutupan kanopi dan jalur transek yang ada di stasiun pengamatan. Jalur transek didapat dari bentukan jalan setapak yang sudah tersedia dengan sendirinya akibat adanya aktivitas manusia yang menggunakan area pengamatan. Jalur tersebutlah yang digunakan untuk mengamati dan melakukan penelitian di setiap tipe habitat. Berikut hasil dokumentasi pribadi yang menggambarkan empat tipe stasiun penelitian. 


\section{UNIVERSITAS BANGKA BELITUNG}

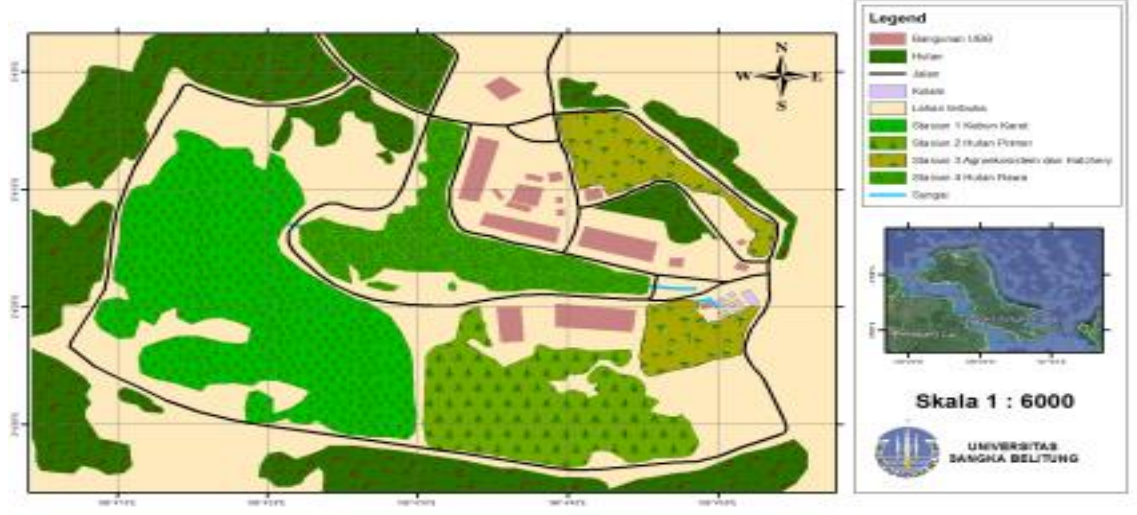

Gambar 1. Lokasi penelitian inventarisasi kupu-kupu di Universitas Bangka Belitung (Sumber: Pribadi 2020)

Data dikumpulkan dengan berjalan mengikuti arah transek Pollard (Rahayu \& Basukriadi 2012). Arah transek pada penelitian ini mengikuti jalan setapak bervegetasi yang terdapat pada setiap stasiun. Sampel kupu-kupu dikumpulkan dengan jalan mengikuti arah transek dengan stabil (Wiranti 2019). Pada jarak 5 meter kekiri, kanan dan depan jumlah kupukupu yang ditemukan dicatat dalam lembar penelitian. Observasi pendahuluan dengan penjelajahan setiap lokasi penelitian di seluruh habitat. Hasil pengamatan tipe habitat kupu-kupu di sekitar kampus UBB ditentukan tipe habitat yang menjadi lokasi pengamatan, yaitu kebun karet, hutan sekunder, hatchery dan agroekosistem, dan hutan rawa. Penelitian dilakukan dengan jalur transek sepanjang \pm 500 $\mathrm{m}$ mengikuti jalan setapak bervegetasi yang terdapat pada setiap stasiun penelitian. Jalur transek menyesuaikan dengan keadaan masingmasing tipe habitat.

Penelitian dilaksanakan pada pagi hari pukul 08.00-11.00 dan sore hari 13.00-16.00 WIB (Barua et al. 2010). Pengambilan kupu-kupu dilaksanakan selama \pm 5 hari di setiap habitat stasiun penelitian. Apabila kondisi cuaca di lapangan tidak baik, seperti turun hujan dan angin kencang, maka pengamatan dilanjutkan pada hari berikutnya. Kupu-kupu yang terlihat diupayakan untuk ditangkap menggunakan jaring serangga atau dicatat dalam lembar pengamatan.

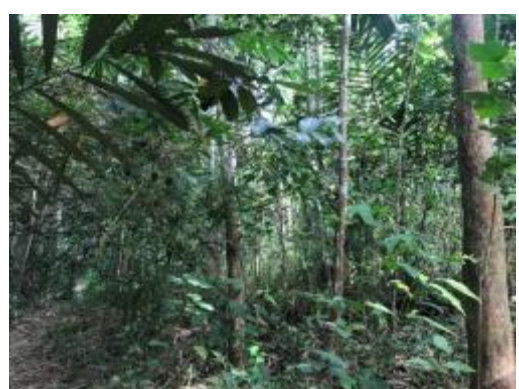

(a)

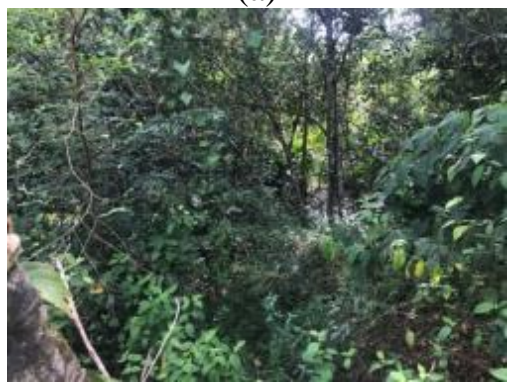

(c)

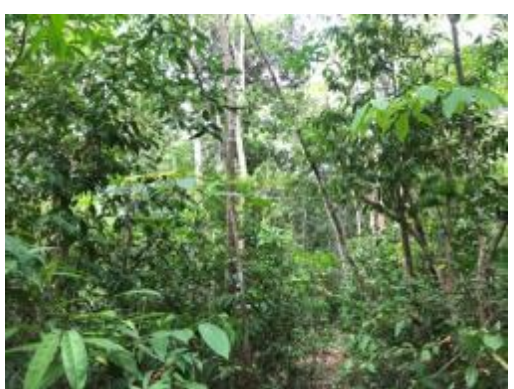

(b)

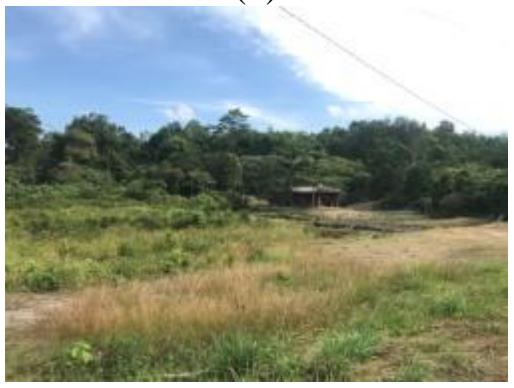

(d)

Gambar 2. Universitas Bangka Belitung (a) Kebun karet (b) Hutan sekunder (c) Hatchery dan Agroekosistem (d) Hutan Rawa. 


\section{Identifikasi Kupu-kupu}

Buku yang digunakan merujuk pada Butterflies of West Malaysia and Singapore second Edition (Fleming 2009), Butterflies of The South East Asian Islands Part I Papilionidae, Part II Pieridae, Danaidae, Part III Satyridae, Part IV Nymphalidae (I), dan Part V Nymphalidae (II) (Tsukada1991) dan Practical Guide to the Butterfly of Bogor Botanic Garden (Peggie \& Amir 2006) dan Website Butterflies of India (Kunte et al. 2020). Kupu-kupu juga dibandingkan dengan koleksi kupu-kupu yang ada di Laboratorium Entomologi bidang Zoologi LIPI melalui dokumentasi jenis kupu-kupu. Proses identifikasi ini dilakukan dengan persetujuan Prof. Dr. Hari Sutrisno yang langsung mengidentifikasi kupu-kupu melalui dokumentasi.

\section{Analisis Data}

Data kupu-kupu dianalisis untuk mengetahui nilai kelimpahan spesies, indeks keanekaragaman spesies, indeks kekayaan jenis dan kemerataannya.Uji kolerasi Pearson dengan software SPSS 16 untuk mengetahui hubungan faktor lingkungan dengan jumlah spesies dan jumlah individu (Pudjirahardjo et al. 1993). Nilai kelimpahan spesies dinyatakan dalam jumlah tiap masing-masing jenis (Magurran 1988).

$$
\mathrm{P} i=\frac{\sum \text { spesies } i}{\sum \text { total spesies }}
$$

Indeks Keanekaragaman kupu-kupu dengan indeks diversitas Shannon-Wiener

$$
\mathrm{P} i=\frac{\sum \text { spesies } i}{\sum \text { total spesies }}
$$

Indeks Kekayaan dengan indeks kekayaan jenis Margalef

$$
\mathrm{D}_{\mathrm{MG}}=\frac{\mathrm{S}-1}{\log (\mathrm{N})}
$$

Indeks Kemerataan setiap famili

$$
\mathrm{E}=\frac{\mathrm{H}^{\prime}}{\log \mathrm{S}}
$$

\section{HASIL DAN DISKUSI}

\section{Tipe Habitat di Universitas Bangka Belitung}

Tipe vegetasi pada habitat kebun karet dan habitat hutan sekunder menunjukkan kesamaan vegetasi yang banyak dijumpai adalah tumbuhan seperti Hevea brasiliensis (Will. ex A.Juss.),
Schima wallichii Choisy., Pithecellobium jiringa (Jack) Merr., dan Artocarpus champeden (Thunb.) Merr.. Habitat hutan sekunder tipe vegetasinya banyak terdapat tumbuhan produksi buah seperti Parkia speciosa Hassk, Artocarpus champeden (Thunb.) Merr., Nephelium lappaceum L., Durio zibethinus Murr. dan Pithecellobium jiringa (Jack) Merr.

Habitat hatchery dan agroekosistem memilki vegetasi yang sangat berbeda, vegetasi dominannya tergolong dalam herba dan semak seperti Imperata cylindrica (L.) Raeusch, Scleria levis Willd., dan Melastoma malabathricum L. Vegetasi pada habitat juga tidak memiliki tutupan kanopi karena termasuk dalam lahan terbuka. Tumbuhan yang ada diarea agroekosistem saat penelitian didominasi ilalang yang menutupi lahan, ada beberapa tanaman penghasil bunga seperti Syzygium aqueum dan Ixora acuminata. Vegetasi hutan rawa di area penelitian cukup beragam seperti terdapat pohon rumbia (Metroxylon sagu Rottb.), pohon kiacret (Spathodea campanulata Beauv.), pohon karet (Hevea brasiliensis (Will. ex A.Juss.)), dan mahar damar (Macaranga triloba (B1.) Muell Arg.).

\section{Keanekargaman Kupu-Kupu di Universitas Bangka Belitung}

Berdasarkan hasil indeks keanekargaman Shannon-Winner (H') kupu-kupu di setiap tipe habitat memiliki kriteria keanekaragaman spesies sedang, yaitu $1<\mathrm{H}^{\prime}<3$. Indeks kemerataan (E) pada seluruh tipe habitat termasuk dalam kondisi penyebaran jenis stabil, hal ini dikarenakan jika E $0,21<\mathrm{E}<1$ disimpulkan penyebarannya termasuk stabil. Indeks kekayaan jenis Margalef $\left(D_{M G}\right)$ kupu-kupu pada seluruh tipe habitat menunjukkan tingkat kekayaan jenis yang sedang, yaitu dengan kreteria $2,5>\mathrm{D}_{\mathrm{MG}}>4$.

Nilai indeks keanekaragaman ShannonWinner (H') di seluruh tipe habitat yaitu 2,70 yang menunjukan keanekaragaman spesies sedang, dengan nilai kemerataan 0,82 yang artinya dalam lingkup kemerataan spesies yang stabil. Indeks kekayaan jenis seluruh habitat memiliki nilai 3,81 yang menunjukkan kekayaan jenis sedang. Menurut Odum (1996), habitat yang termasuk dalam keanekaragaman sedang mempunyai produktivitas yang cukup menunjang keberlangsungan hidup suatu makhluk hidup dengan kondisi ekosistem seimbang serta tekanan ekologis sedang hingga rendah. 
Tabel 1. Keanekaragaman Shannon-Winner $\left(\mathrm{H}^{\prime}\right)$, kemerataan $(\mathrm{E})$, dan kekayaan jenis Margalef $\left(\mathrm{D}_{\mathrm{MG}}\right)$ kupu-kupu pada masing-masing stasiun

\begin{tabular}{ccccc}
\hline \multirow{2}{*}{ Analisis } & \multicolumn{4}{c}{ Stasiun } \\
\cline { 2 - 5 } & I & II & III & IV \\
\hline Indeks kemerataan Shannon-Winner (H') & 2,32 & 2,31 & 1,95 & 2,43 \\
Indeks kemerataan (E) & 0,79 & 0,82 & 0,85 & 0,98 \\
Indeks kekayaan jenis Margalef $\left(\mathrm{D}_{\mathrm{MG}}\right)$ & 3,03 & 2,85 & 3,91 & 2,52 \\
\hline
\end{tabular}

Ket: I(Kebun karet), II(Hutan sekunder), III(Agroekosistem dan hatchery), IV(Hutan rawa)

Indeks keanekaragaman Shannon-Winner $\left(\mathrm{H}^{\prime}\right)$ tertinggi di peroleh di stasiun rawa $\left(\mathrm{H}^{\prime}=\right.$ $2,43)$ dan indeks kemerataan $(\mathrm{E}=0,98)$. Habitat rawa mempunyai perbedaan dengan habitat lainnya, dimana tepiannya dinaungi oleh sedikit kanopi. Hal ini yang menyebabkan variasi masuknya cahaya matahari secara langsung. Menurut Hammer et al. (2003) cahaya matahari yang ada mempengaruhi kesukaan setiap kupukupu secara berbeda. Nilai indeks keanekaragaman terendah terdapat di hatchery dan agroekosistem $\left(\mathrm{H}^{\prime}=1,95\right)$ diikuti kemerataan spesies $(E=0,85)$. Nilai keanekargaman di hatchery dan agroekosistem memang paling rendah, tetapi nilai kemerataan cukup stabil di antara semua habitat. Hal ini menunjukan bahwa di habitat tersebut keanekaragaman rendah tetapi tidak ada satu spesies yang mendominasikan spesies lainnya. Indeks kemerataan terendah terdapat di habitat kebun karet $(E=0,79)$, meskipun indeks keanekargaman spesies bukan yang terendah. Hal ini menunjukan bahwa adanya satu spesies yang mendominasi spesies lainnya. Spesies yang mendominasi pada habitat kebun karet adalah Eurema sari Moore. Spesies ini memang ditemukan pada seluruh habitat, tetapi mendominasi di kebun karet. Tingginya nilai kemerataan spesies mengindikasikan bahwa jumlah individu setiap spesies semakin seragam (Winarni 2005).

Indeks kekayaan jenis pada kebun karet yaitu 3,03, hutan sekunder 2,85, hatchery dan agroekosistem 3,91, dan rawa 2,52. Kekayaan spesies yang ditemukan pada kebun karet 19 spesies, hutan sekunder 17 spesies, hatchery dan agroekosistem 10, dan lokasi. Nilai indeks kekayaan jenis pada kebun karet dan hatchery dan agroekosistem tidak jauh berbeda, tetapi jika dibandingkan habitat ini memiliki perbedaan anggota spesiesnya. Indeks kekayaan jenis yang tinggi di hatchery agroekosistem diduga karena stasiun tersebut banyak ditumbuhi oleh tumbuhan berbunga penghasil nektar seperti Melastoma malabatricum. Pada habitat ini jenis yang mendominasi yaitu Acraea terpsicore dan Appias olferna. Pada kawasan agroekosistem juga terdapat beberpa tanaman hias yang sengaja ditanam untuk mempercantik kawasan tersebut, sehingga jumlah tumbuhan berbunga lebih banyak daripada habitat lainnya. Menurut Thomas et al. (2004) tumbuhan inang larva dan sumber nektar saat dewasa mempengaruhi keberadaan spesies kupu-kupu. Kemerataan jenis dan kekayaan jenis memperngaruhi nilai indeks keanekaragaman yang menunjukkan tinggirendahnya nilai indeksnya (Rasidi et al. 2008).

Kupu-kupu hasil pengamatan di Universitas Bangka Belitung diperoleh sebanyak 27 jenis dari 4 tipe habitat yang menjadi lokasi pengamatan. Spesies Eurema sari, Mycalesis horsfieldi dan Mycalesis mineus merupakan jenis spesies yang terdapat disemua habitat pengamatan. Spesies E.sari juga individu yang paling banyak ditemukan penyebarannya yaitu 224 individu. Berbeda dengan habitat lainnya pada habitat hatchery dan agroekosistem ditemukan jenis spesies yang tidak ditemukan di habitat lainnya. Jenis kupu-kupu pada hatchery dan agroekosistem ini dominan memiliki warna sayap yang terang. Spesies Appias olferna salah satu spesies yang hanya ditemukan di hatchry dan agroekosistem dengan jumlah individu terbanyak pada habitat tersebut.

Spesies E.sari dapat mendominasi diseluruh habitat disebabkan oleh tersedianya tumbuhan pakan yang dibutuhkan oleh spesies E.sari. Peggie dan Amir (2006) menyatakan bahwa, tumbuhan pakan E.sari sangat bervariasi seperi famili Apocynacea, Arecaceae, Asteraceae, Caesaliniaceae, Euphorbiaceae, Theaceae dan Verbenaceae. 
Tabel 2. Jumlah spesies kupu-kupu

\begin{tabular}{|c|c|c|c|c|c|c|}
\hline \multirow{2}{*}{ No. } & \multirow{2}{*}{ Famili } & \multirow{2}{*}{ Spesies } & \multicolumn{4}{|c|}{ Sindividu } \\
\hline & & & I & II & III & VI \\
\hline 1. & Nymphalidae & Acraea terpsicore Linnaeus & & & 38 & \\
\hline 2. & & Cethosia cyane Drury & 2 & 1 & & \\
\hline 3 & & Cupha erymanthis Sulzer & 20 & 17 & & 5 \\
\hline 4. & & Euploea mulciber Cramer & 6 & 2 & & \\
\hline 5. & & Hypolimnas bolina Linnaeus & & & 13 & \\
\hline 6. & & Hypolimnas misippus Linnaeus & 24 & 5 & & 10 \\
\hline 7. & & Ideopsis juventa Cramer & 30 & 25 & 20 & \\
\hline 8. & & Junonia orithya Linnaeus & & & 30 & \\
\hline 9. & & Mycalesis horsfieldi Moore & 20 & 18 & 7 & 10 \\
\hline 10. & & Mycalesis mineus Frühstorfer & 15 & 22 & 2 & 6 \\
\hline 11. & & Neptis harita Moore & 10 & 5 & & 8 \\
\hline 12. & & Orsotriaena medus Butler & 15 & 12 & & 9 \\
\hline 13. & & Sp 26 & & & & 5 \\
\hline 14. & & Tanaecia cocytina Tsukada & 9 & 1 & & \\
\hline 15. & & Tanaecia jahnu Moore & 2 & & & 3 \\
\hline 16. & & Tanaecia palguna Distant & 79 & 20 & & 7 \\
\hline 17. & & Thaumantis diores Doubleday & 4 & & & \\
\hline 18. & Pieridae & Appias olferna Swinhoe & & & 47 & \\
\hline 19. & & Catopsilia pomona Fabricius & & & 2 & 5 \\
\hline 20. & & Eurema blanda Moore & & & 4 & \\
\hline 21. & & Eurema sari Moore & 109 & 90 & 20 & 5 \\
\hline 22. & & Leptosia nina Fabricius & 3 & 5 & & \\
\hline 23. & Lycaenidae & Neocheritra amrita H.H. Druce & 12 & 20 & & 5 \\
\hline 24. & & Jamides pura Moore & & 5 & & \\
\hline 25. & Hesperidae & Tagiades ultra Evans & 13 & 15 & & \\
\hline 26. & & Unkana ambasa batara & 1 & & & \\
\hline 27. & Riodinidae & Abisara neophron Hewitson & 5 & 10 & & \\
\hline & & $\sum$ spesies & 19 & 17 & 10 & 12 \\
\hline & & $\Sigma$ individu & 379 & 273 & 183 & 78 \\
\hline
\end{tabular}

Sumber pakan bagi E.sari seperti Arecaceae, Apocynacea dan Verbenaceae terdapat di kawasan kampus Universitas Bangka Belitung. Kelimpahan sumber pangan akan berpengaruh secara signifikan terhadap kelimpahan spesies konsumennya (Yamamoto et al. 2007).

Famili Nyamphalidae diperoleh jenis kupukupu paling banyak, yaitu $60 \%$ dari seluruh total kupu-kupu yang didapat, sedangkan kupu-kupu yang paling sedikit didapat ialah dari famili Rhiodinidae yaitu 2\%. Famili Nympalidae merupakan kelompok kupu-kupu yang ditemukan di semua lokasi penelitian, ini di karena kupu-kupu dari famili ini memilki jumlah jenis yang paling besar dan penyebaran yang luas jika dibandingkan dengan kupu-kupu famili lainnya (Efendi 2009). Menurut Braby (2004) menyatakan bahwa famili Nympalidae adalah kelompok kupu-kupu yang memiliki sifat yang kosmopolit artinya memiliki lokasi penyebaran yang luas dan banyak di bagian wilayah dunia, serta memiliki sifat yang polifag artinya memiliki makanan inang yang beragam sehingga mampu hidup di beragam tipe habitat.

Pada beberapa penelitian serupa yang sudah dilakukan, diketahui bahwa famili Nymphalidae adalah kupu-kupu yang paling banyak ditemukan di lokasi penelitian. Pada penelitian keanekargaman jenis kupu-kupu Superfamili Papilionoidea di Hutan Rimbe' Mambang, Desa Dalil menunjukkan famili yang paling banyak ditemukan ialah Nymphalidae dengan persentasi 67\% (29 spesies dari 43 spesies total) (Purwari 2016). Penelitian lain berkaitan dengan keanekaragaman dan distribusi jenis kupu-kupu dilakukan di Hutan Kota Jambi juga diketahui bahwa famili Nympalidae adalah yang paling banyak ditemukan yaitu sebanyak 24 spesies dari 43 spesies total (Rahayu \& Basukriadi 2012). 
Tabel 3. Hasil pengukuran faktor lingkungan rata-rata di masing-masing tipe habitat

\begin{tabular}{lrrrr}
\hline \multirow{2}{*}{ Faktor Lingkungan } & \multicolumn{4}{c}{ Stasiun } \\
\cline { 2 - 5 } & \multicolumn{1}{c}{ I } & \multicolumn{1}{c}{ II } & \multicolumn{1}{c}{ III } & \multicolumn{1}{c}{ IV } \\
\hline Kecepatan Angin $(\mathrm{m} / \mathrm{s})$ & 0,15 & 0,19 & 1,82 & 0,69 \\
Suhu udara $\left({ }^{\circ} \mathrm{C}\right)$ & 26,22 & 27,23 & 31,15 & 28,81 \\
Kelembaban Udara (\%) & 84,92 & 82,21 & 48,63 & 80,31 \\
Intensitas cahaya (Klx) & 4,35 & 3,57 & 19,74 & 6,22 \\
\hline
\end{tabular}

Kupu-kupu yang paling sedikit ditemukan ialah famili Rhiodinidae. Kupu-kupu dari famili ini hanya ditemukan satu spesies saja, yaitu Abisara neophron. Spesies ini ditemukan di habitat yang hampir sama tipe vegetasinya yaitu pada kebun karet dan hutan sekunder. Hal ini diduga karena tanaman inang untuk kupu-kupu tersebut yang hanya ada di kedua habitat tersebut. Selain itu famili Riodinidae ini juga jarang sekali ditemukan karena kebiasaannya berada di bawah permukaan daun pada saat istirahat seperti kupu-kupu malam (moth) (Smart 1991).

\section{Pengukuran Faktor Lingkungan terhadap Keberadaan Kupu-kupu di Universitas Bangka Belitung}

Pada pengukuran faktor lingkungan digunakan pengukuran kecepatan angin $(\mathrm{m} / \mathrm{s})$, suhu udara $\left({ }^{0} \mathrm{C}\right)$, kelembaban udara $(\%)$, dan intensitas cahaya (Klx). Hasil pengukuran akan dihubungkan dengan hasil keberadaan jenis kupu-kupu yang ditemukan di Universitas Bangka Belitung. Berdasarkan hasil pengukuran di lapangan, habitat dengan keadaan ekstrim yaitu pada habitat hatchery dan agroekosistem. Hal ini didasari oleh hasil suhu udara yang mencapai $31^{\circ} \mathrm{C}$ dan intensitas cahaya sebesar 19 $\mathrm{Klx}$.

Berdasarkan hasil pengukuran di kebun karet dan hutan sekunder menunjukkan nilai ratarata suhu udara $26-27^{\circ} \mathrm{C}$, habitat hatchery dan agroekosistem $30-31^{\circ} \mathrm{C}$ dan hutan rawa rata-rata $28-29^{\circ} \mathrm{C}$. Kecepatan angin pada kebun karet dan hutan sekunder $0,15-0,19 \mathrm{~m} / \mathrm{s}$, hatchery dan agroekosistem $1,82 \mathrm{~m} / \mathrm{s}$ dan hutan rawa $0,69 \mathrm{~m} / \mathrm{s}$. Kelembaban udara di kebun karet dan hutan sekunder $82-84 \%$, hatchery dan agoekosistem $46-48 \%$, dan hutan rawa $79-80 \%$. Intensitas cahaya di kebun karet dan hutan sekunder 3-4 $\mathrm{klx}$, hatchery dan agroekosistem 19-20 klx, dan hutan rawa 5-6 klx.

Kondisi suhu, kelembaban udara, kecepatan angin dan intensitas cahaya pada setiap stasiun berperan penting terhadap keberadaan jenis kupu-kupu. Berdasarkan pengetahuan meskipun kupu-kupu diketahui sebagai satwa yang memiliki sifat polikilotermik yaitu suhu tubuhnya akan meningkat atau menurun mengikuti kondisi lingkungan sekitarnya (Sihombing 2002), namun kupu-kupu memiliki kemampuan adaptasi yang berbeda-beda terhadap perubahan suhu dan kelembaban habitatnya. Pada bulan Maret 2020 menurut data BMKG Stasiun Meteorologi Depati Amir rata-rata suhu udara mencapai $27^{\circ} \mathrm{C}$, kelembaban udara $85 \%$, kecepatan angin $2,8 \mathrm{~m} / \mathrm{s}$ dan curah hujan 1234,8 mm. Bulan Juni suhu udara $27^{\circ} \mathrm{C}$, kelembaban udara $80 \%$, kecepatan angin $2,33 \mathrm{~m} / \mathrm{s}$ dan curah hujan $894,7 \mathrm{~mm}$.

Pengukuran kolerasi pearson antara jumlah spesies dan jumlah individu kupu-kupu yang ditemukan di seluruh habitat dapat dilihat pada Tabel 3. Pengukuran ini melihat ada tidaknya hubungan antara faktor lingkungan terhadap keberadaan kupu-kupu dari keseluruhan habitat penelitian. Hasil dari nilai kolerasi pearson didapatkan berdasarkan jumlah kupu-kupu yang ditemukan dengan kondisi lingkungannya. Pengukuran ini menggunakan analisis uji kolerasi Pearson pada software SPSS 18.

Tabel 4. Nilai Kolerasi Pearson antara jumlah spesies dengan parameter lingkungan

\begin{tabular}{lcc}
\hline \multicolumn{1}{c}{ Parameter lingkungan } & $\Sigma$ Spesies & $\Sigma$ Individu \\
\hline Kecepatan angin & $-0,893$ & $-0,686$ \\
Suhu udara & $-0,965$ & $-0,517$ \\
Kelembaban udara & 0,783 & 0,338 \\
Intensitas cahaya & $-0,792$ & $-0,346$ \\
\hline
\end{tabular}


Hasil analisis uji kolerasi pearson untuk melihat kolerasi yang terjadi antara parameter jumlah spesies dan individu dengan parameter lingkungannya. Hubungan antara kondisi suhu udara dengan jumlah jenis menunjukkan semakin tinggi sugu pada habitat maka akan semakin rendah jumlah spesies dengan koefisiesn kolerasi Pearson bernilai negatif $(r=-0,965)$ maupun hubungan jumlah individu $(\mathrm{r}=-0,686)$. Suhu udara yang menunjukkan jumlah spesies tertinggi (19) dan jumlah individu (379) adalah suhu $\pm 26^{\circ} \mathrm{C}$. Suhu yang menunjukkan jumlah spesies terendah (10) adalah $\pm 31^{\circ} \mathrm{C}$, sedangkan kisaran suhu jumlah individu terendah (78) adalah $\pm 29^{\circ} \mathrm{C}$.

Hubungan jumlah spesies dan individu dengan kelembaban udara memiliki koefisiesn kolerasi Pearson bernilai positif $(r=0,783)$ dan $(r$ $=0,338)$. Arah hubungan adalah positif yang menunjukkan bahwa semakin tinggi kelembaban udara maka jumlah spesies dan individu semakin meningkat. Kelembaban udara dari seluruh habitat diperoleh rata-rata $48,63 \%$ - 84,92\%. Kupu-kupu mempunyai rentan kelembaban udara tertentu untuk beraktivitas secara optimal yaitu $60-75 \%$, sedangkan saat berkembang biak kelembaban yang dibutuhkan lebih tinggi yaitu antara 84-92\%, namun kupu-kupu tidak mampu beradaptasi pada area yang memiliki kelembaban terlalu tinggi hingga mencapai $>92 \%$ (Borror $e t$ al. 1992).

Hubungan jumlah spesies dan individu dengan intensitas cayaha memiliki koefisiesn kolerasi Pearson bernilai negatif $(r=-0,792)$ dan $(\mathrm{r}=-0,346)$. Arah hubungannya adalah negatif yang menunjukan semakin tinggi nilai intensitas cahaya yang masuk jumlah spesies dan individu semakin rendah. Intensitas cahaya diukur diseluruh habitat memiliki nilai yang berbeda, terutama pada habitat hatchery dan agroekosistem dengan nilai tertinggi 19,74 klx. Hal ini diduga karena pada hatchery dan agroekosistem merupakan lahan terbuka yang luas dan tidak memiliki vegetasi pohon, sehinggga cahaya matahari langsung mengenai area. Pada habitat kebun karet, hutan sekunder dan hutan rawa rata-rata intensitas cahayanya 3,57-6,22 klx. Pada ketiga stasiun ini tutupan kanopi tidak terlalu besar dan juga kecil, cahaya matahari masih dengan mudah menyentuh lantai hutan. Pada ketiga habitat ini juga jumlah jenis banyak ditemukan, hal ini menunjukan bahwa tutupan kanopi dan masuknya intensitas cahaya mempengaruhi jumlah jenis kupu-kupu pada habitat tersebut (Koh \& Sodhi 2004).
Faktor lingkungan yaitu angin sangat berpengaruh bagi keberadaan dan kelangsungan hidup kupu-kupu pada habitat (Fitri, 2015). Berdasarkan nilai kecepatan angin rata-rata 0,15 $1,82 \mathrm{~m} / \mathrm{s}$. Hal ini menunjukan perbedaan yang jauh di stasiun tiga, diduga karena stasiun hatcery dan agroekosistem merupakan lahan terbuka yang tidak memiliki hambatan saat angin berhembus. Nilai tertinggi pada kecepatan angin masih dalam batasan wajar, menurut Utami (2012), kecepatan angin yang dapat ditoleransi yaitu tidak lebih dari skala 5 berdasarkan skala Beaufort. Kencangnya tiupan angin dapat membuat kupu-kupu mengalami dehidrasi pada saat terbang. Hasil analisis kolerasi Pearson pada kecepatan angin dengan jumlah spesies dan individu bernilai negatif dengan $(\mathrm{r}=-0,792)$ dan $(\mathrm{r}=-0,346)$. Arah hubungan yang negatif menunjukkan semakin tinggi kecepatan angin makan jumlah spesies dan individu semakin rendah.

\section{KESIMPULAN}

Berdasarkan hasil keseluruhan mengenai inventarisasi jenis kupu-kupu (Lepidoptera: Papilionoidea) di beberapa tipe habitat di Universitas Bangka Belitung, menunjukkan bahwa keanekaragamn kupu-kupu masuk dalam kategori tinggi dengan kelimpahan famili tertinggi Nymphalidae sebanyak $60 \%$. Keragaman jenis kupu-kupu tertinggi terdapat pada habitat kebun karet dikarenakan jenis keragaman vegetasi dan faktor lingkungan pada habitat ini, dengan jumlah spesies (19) dan individu (379). Spesies memiliki persebaran diseluruh stasiun adalah Eurema sari.

\section{UCAPAN TERIMA KASIH}

Terima kasih kepada program studi Biologi Fakultas Pertanian, Perikanan dan Biologi Universitas Bangka Belitung. Kepada Budi Afriyansyah, S.Si., M. Si. dan Prof. Dr. Hari Sutrisno selaku pembimbing skripsi, serta semua pihak yang telah banyak memberikan bantuan dalam penyelesaian penelitian ini. Ucapana terima kasih juga kepada pihak JSN (Jurnal Sains Natural) yang memberikan kesempatan untuk penelitian ini dapat dipublikasikan. 


\section{DAFTAR PUSTAKA}

Almaidah, S. R. (2005). Keanekaragaman Jenis Kupu-kupu di Desa Citalahab dan Hutan dalam Kawasan Taman Nasional Gunung Halimun Jawa Barat (skripsi). Universitas Islam As-Syafi'iyah.

Bahar I, Atmowidi T \& Peggie D. (2016). Keanekaragaman Kupu-Kupu Superfamili Papilionoidea (Lepidoptera) Di Kawasan Hutan Pendidikan Gunung Walat Sukabumi, Jawa Barat. Zoo Indonesia, 25(1), 71-82.

Barua K M, Slowik J, Bobo K S \& Muehlenberg M. (2010). Correlation of rainfall and forest type with Papilionid assemblages in Assam in North East India. Psyce, 2010, 1-10.

Braby M F. (2004). The Complete Fiels Guide to Butterflies of australia. Canbera: CSIRO Publishing.

Borror D J, Triplehorn C A \& Johnson N F. (1992). Pengenalan Pelajaran Serangga. Yogyakarta: Universitas Gadjah Mada Press penyunt. s.l.:s.n.

Dewenter, I. \& Tscharntke, T. (2000). Butterfly Community in Fragmented Habitats. Ecology Letters, 3, 449-456.

Efendi, M A. (2009). Keragaman Kupu-kupu (Lepidoptera: Ditrysia) di Kawasan Hutan Koridor Taman Nasional Gunung HalimunSalak Jawa Barat (tesis). Institut Pertanian Bogor. Bogor.

Fitri, H N. (2015). Keanekaragaman dan Kelimpahan Kupu-kupu (Lepidoptera) di Kawasan Hutan Pantai Leuwung Sancang Kecamatan Cibalong Kabupaten Garut (skripsi). Universitas Pendidikan Indonesia. Bandung.

Fleming, W. (2009). Butterflies of West Malaysia and Singapore. Faringdon.

Helmiyetti, Manaf S. \& Sinambela, K.. (2012). Jenis-jenis kupu-kupu (butterflies) yang terdapat di Taman Nasional Kerinci Seblat Resor Ketenong Kecamatan Pinang Belapis Kabupaten Lebong Propinsi Bengkulu. $J$ Konservasi Hayati, 8(1), 22-28.

Hoskins, A. (2012). Learn About Butterflies: the complete guide to the world of butterflies and moths. www.learnaboutbutterflies.com.
Kunte, K S., Sondhi, Roy (2020). Butterflies of India, v. 2.90. Indian Foundation for Butterflies. https://www.ifoundbutterflies.org/

Kitching R L. (1999). Biology of Australian Butterflies.Australia (ID): CSIRO Publishing.

Koh K P \& Sodhi N S. (2004). Importance of reverse, fragments and parks for butterfly conservation in a tropical urban lanscape. Ecological Applications. 14(6), 1695-1708.

Magurran, A E. (1988). Ecological diversity and its measurement. New Jersey: Princeton University Press.

Odum, E P. (1996). Dasar-dasar Ekologi; Edisi Ketiga. Yogyakarta: Gadjah Mada University Press, Penerjemah Samingan, Tjahjono.

Peggie, D. (2014). Diversitas dan Pentingnya Kupu-kupu Nusa Kambangan (Jawa, Indonesia). Zoo Indonesia, 23(1), 45-55.

Peggie, D \& Amir, M. (2006). Practical Guide nto the Butterflies of Bogor Botanic Garden. Cibinong: Bidang Zoologi Pusat Penelitian Biologi LIPI.

Pudjirahardjo, W. J. (1993). Pemilihan Uji Statistik. Di dalam : Poerwadi T, Poernomo H. Machfoed H, editor. Metode Penelitian dan Statistik Terapan. Surabaya : Airlangga University Press.

Rahayu S E \& Basukriadi A. (2012). Kelimpahan dan Keanekaragaman Spesies Kupu-Kupu (Lepidoptera; Rhopalocera) Pada Berbagai Tipe Habitat di Hutan Kota Muhammad Sabki Kota Jambi. Biospecies, 5(2), 40-48.

Rasidi, S., Basukriadi A., Ischak, Tb. M. (2008). Ekologi hewan. Jakarta: Penerbit Universitas Terbuka.

Renstra UBB. (2017) Rencana Strategis Universitas Bangka Belitung 205-2019. Balunijuk: Universitas Bangka Belitung

Sihombing, D. T. H. (2002). Satwa Harapan I Pengantar Ilmu Dan Teknologi Budidaya. Bogor: Pustaka Wirausaha

Smart, P. (1991). Illustrared Encyclopedia of the Butterfly World Over 2000 Spesies. Eveneu Park: Live Size New York.

Solman, R., (2004). Nectar host plants of some butterfly species at Visakhapatnam. Science and Culture, 70, 187-190. 
Thomas, J. A., Telfer, M. G., Roy, D.B., Preston, C. D., Greenwood, J. J. D., Asher, J., Fox, R., Clarke, R.T. \& Lawton, J. H. (2004). Comparative losses of british butterflies, bird, and plants and the global extinction. Science. 303, 1879-1881.

Tsukada, E. (1991). Nymphalidae (II). In E. Tsukada. (Editor), Butterflies of the South East Asian Islands V. Japan: Plapac Co. Ltd..

Utami, E N. (2012). Komunitas Кири-kири (Ordo Lepidoptera: Papilionoidea) di Kampus Universitas Indonesia Depok, Jawa Barat (skripsi). Universitas Indonesia. Depok.
Winarni, N. L. (2005). Analisa sederhana dalam ekologi hidupanliar. Penelitian survei biodiversity in Island communities, Way Canguk.

Wiranti, D., Nurtjahya, E., Dahelmi. (2019). Short Communication: The diversity of butterflies (Superfamily Papilionoidea) as a success indicator of tin-mined land revegetation. Biodiversitas, 20, 1923-1928.

Yamamoto, N., Yokoyama, J., \& Kawata, M. (2007). Relative resource abundance explains butterfly biodiversity in island communities. PNAS, 104(25), 10524-10529. 